\title{
Reassessment of the advertisement call of topotypic Scinax squalirostris (Anura: Hylidae), with an acoustic evaluation of its occurrence in the Serra da Mantiqueira, southeastern Brazil
}

\author{
Ariovaldo Antonio Giaretta, ${ }^{1}$ André Gomes Lopes, ${ }^{1,2}$ and Davi Lee Bang ${ }^{1,2,3}$ \\ ${ }^{1}$ Laboratório de Taxonomia e Sistemática de Anuros Neotropicais, Instituto de Ciências Exatas e Naturais do Pontal, \\ Universidade Federal de Uberlândia. 38304-402, Ituiutaba, MG, Brazil. E-mail: aagiaretta@gmail.com \\ ${ }^{2}$ Programa de Pós-Graduação em Biologia Comparada, Departamento de Biologia, Faculdade de Filosofia, Ciências e Letras \\ de Ribeirão Preto (FFCLRP), Universidade de São Paulo. 14040-901, Ribeirão Preto, SP, Brazil. \\ ${ }^{3}$ Laboratório de Zoologia de Vertebrados, Faculdade de Filosofia, Ciências e Letras de Ribeirão Preto (FFCLRP), Universidade \\ de São Paulo. 14040-901, Ribeirão Preto, SP, Brazil.
}

\begin{abstract}
Reassessment of the advertisement call of topotypic Scinax squalirostris (Anura: Hylidae), with an acoustic evaluation of its occurrence in the Serra da Mantiqueira, southeastern Brazil. Scinax squalirostris (Lutz, 1925) is thought to occur along a broad range in South America. The values reported for calls of topotypes differ substantially among studies. Because vocalizations often play a key role in uncovering cryptic diversity, the call of $S$. squalirostris is herein redescribed based on a new sample of topotypes. The call of a population from Poços de Caldas, Minas Gerais state, is also described. Topotypic advertisement calls have a dominant frequency between 3970 and $4125 \mathrm{~Hz} ; 13-15$ notes emitted at a rate of $24-27 / \mathrm{s}$; call rate of $67 / \mathrm{min}$ and duration of $0.52-0.61 \mathrm{~s}$; mid-call notes having 6 or 7 well-defined pulses, and an intra-note pulse rate of 223-266/s. Calls of the Poços de Caldas population have dominant frequency between 4083 and $4358 \mathrm{~Hz} ; 15-18$ notes emitted at a rate of $32-34 / \mathrm{s}$; call rate of $64 / \mathrm{min}$ and duration of $0.46-0.56 \mathrm{~s}$; mid-call notes having 6 or 8 well-defined pulses, and an intra-note pulse rate of 252-312/s. The advertisement calls of these populations have some differences with each other, and are promptly distinguished from calls of morphologically similar species. Our data to topotypes are inconsistent with some previously reported. A more detailed study of the population from Poços de Caldas is required, and more marked differences may be found in populations more distant from type locality of S. squalirostris.
\end{abstract}

Keywords: Amphibia, Atlantic Forest, bioacoustics, taxonomy, vocalization. 


\begin{abstract}
Resumo
Reavaliação do canto de anúncio de Scinax squalirostris (Anura: Hylidae) topotípica, com uma avaliação acústica de sua ocorrência na Serra da Mantiqueira, sudeste do Brasil. Scinax squalirostris (Lutz, 1925) é tida como de ampla ocorrência na América do Sul. Os valores relatados para cantos de topótipos diferem substancialmente entre estudos. Como as vocalizações geralmente desempenham um papel fundamental na descoberta da diversidade críptica, o canto de topótipos de S. squalirostris é aqui redescrito com base em uma nova amostra. O canto de uma população de Poços de Caldas, estado de Minas Gerais, também é descrito. Os cantos topotípicos têm frequência dominante entre 3970 e $4125 \mathrm{~Hz}$; $13-15$ notas emitidas a uma taxa de 24-27/s; taxa de canto de 67/ min e duração de 0,52-0,61 s; notas do meio do canto possuindo 6 ou 7 pulsos bem definidos, e uma taxa de pulsos intra-nota de 223 a 266/s. Os cantos da população de Poços de Caldas têm frequência dominante entre 4083 e $4358 \mathrm{~Hz} ; 15$ a 18 notas emitidas a uma taxa de 32 a 34/s; taxa de canto de 64/min e duração de $0,46-0,56$ s; notas do meio do canto possuindo 6 ou 8 pulsos bem definidos, e uma taxa de pulsos intra-nota de 252-312/s. Os cantos de anúncio dessas populações tem algumas diferenças entre si, e são prontamente distinguidos dos cantos de espécies morfologicamente semelhantes. Nossos dados para topótipos são inconsistentes com alguns relatados anteriormente. É necessário um estudo mais detalhado da população de Poços de Caldas, e diferenças mais acentuadas devem ser encontradas em populações mais distantes da localidade-tipo de $S$. squalirostris.
\end{abstract}

Palavras-chave: Amphibia, bioacústica, Mata Atlântica, taxonomia, vocalização.

\section{Introduction}

Scinax squalirostris (Lutz, 1925) was described from the Serra da Bocaina highlands (Bokermann 1966, Lutz 1973), near the boundary between the Brazilian states of São Paulo and Rio de Janeiro. The species is thought to be distributed in the Atlantic Forest (Lutz 1973, Kwet 2001, Trevine et al. 2014), Cerrado (Eterovick and Sazima 2004, Pombal et al. 2011, São-Pedro and Feio 2011), and Pantanal (Uetanabaro et al. 2008) biomes in Brazil, to Uruguay, Paraguay, Argentina (Straneck et al. 1993), and Bolivia (De la Riva et al. 2000).

Barrio (1963), Haddad et al. (1988), Pombal et al. (1995, 2011), Faria et al. (2013), and Garey et al. (2018) presented data on calls of different populations of Scinax squalirostris, with the two latter studies also reporting on the call of the topotypic population. However, reported values for call variables of topotypes differ substantially among these studies. Given these inconsistencies and the need to elucidate the acoustic parameters of $S$. squalirostris, we redescribe its advertisement call based on a new sample of topotypes. It is likely that $S$. squalirostris may comprise a species complex across its presumptive range (Pombal et al. 2011, Faria et al. 2013); thus, it is important to redescribe and authenticate its advertisement call, because vocalizations can be a key to the identification of cryptic diversity among frogs (e.g., Nunes et al. 2012, Caminer and Ron 2014, Ron et al. 2018, Carvalho et al. 2019). To determine if there is inter-populational variation in advertisement calls, we report call data of a population from the Poços de Caldas Plateau in the Mantiqueira Range in the state of Minas Gerais (MG). The call data from these two populations are compared to those reported in literature for other populations of $S$. squalirostris, as well to those reported for morphologically similar congeners.

\section{Materials and Methods}

On 11 January 2012, calls of Scinax squalirostris $(N=3$ males) were recorded at a site $\left(22^{\circ} 43^{\prime} 35.16^{\prime \prime} \mathrm{S}, 44^{\circ} 37^{\prime} 18.80^{\prime \prime} \mathrm{W}\right.$; ca. 1500 $\mathrm{m}$ a.s.1.) $7 \mathrm{~km}$ from the type locality of the species (Fazenda do Bonito, RPPN Caburé, 
around 2244'22.99" S, 44³3'8.87" W), São José do Barreiro, São Paulo state (SP), Brazil. On 30 January 2009, calls ( $N=3$ males) were recorded in Poços de Caldas (MG), Brazil (21 ${ }^{\circ} 56^{\prime} 57.97^{\prime \prime}$ S, 46³3'29.35” W; ca. $1300 \mathrm{~m}$ a.s.1.). The frogs were identified as $S$. squalirostris based on the descriptions of Lutz (1925) and Lutz (1973), as follow: (1) relatively small body size (males ca. $25 \mathrm{~mm} \mathrm{SVL);} \mathrm{(2)} \mathrm{elongated}$ snout; (3) dorsolateral silvery stripe enclosed by two dark longitudinal stripes; (4) dark canthal line bordered by a white line; and (5) no transverse stripes on limbs.

Only one type of vocalization was heard and recorded. We assume this was the advertisement call because it was emitted repeatedly by males (Toledo et al. 2015, Köhler et al. 2017); it also corresponds in general to the structure of the advertisement call reported by Pombal et al. (1995) for another population. Recordings were made with a Sennheiser ME67/K6 directional microphone, connected to a Marantz PMD 671 or a M-Audio MicroTrack II digital recorder set to a sampling rate of $44.1 \mathrm{kHz}$ and 16-bits resolution. Ten calls of each frog were analyzed. Call features were measured in Raven Pro 1.5 software (Bioacoustics Research Program 2014) with the following settings: $50 \%$ brightness and contrast; Hann window function at FFT width of 256 samples; $3 \mathrm{~dB}$ filter bandwidth of $270 \mathrm{~Hz}$; overlap (locked) at 85\%; and DFT size at 1024 samples. We followed the note-centered approach of Köhler et al. (2017) to define call units, therefore considering the main sound unit as a call, which is composed of subunits we treated as notes, which are in turn composed of pulses. Calls were measured from parts of the recording in which the vocalizations had higher and stable amplitudes. The acoustic terminology and definitions adopted are summarized in Table 1. Dominant frequency was obtained using the "Peak Frequency" function of Raven Pro 1.5. Sound figures were made using the Seewave package v. 1.5.9 (Sueur et al. 2008) in the $\mathrm{R}$ platform v. 2.12.1 (R Development Core Team
2014), using Hann window function, $85 \%$ overlap, and 256 points resolution (FFT). Call vouchers (AAG-UFU 0834-5; 1129-35) and recordings are housed in the Coleção de Anuros do Museu de Biodiversidade do Cerrado (AAGUFU), Universidade Federal de Uberlândia, Uberlândia, Minas Gerais state, Brazil. The recordings analyzed are listed in Appendix I; a recording analyzed in Garey et al. (2018) was directly compared with our samples.

We sought for acoustic discrimination between topotypes and specimens from Poços de Caldas by applying the "DAPC" (Discriminant Analysis on Principal Components) function (adegenet v. 2.0.1 R package; Jombart 2008, Jombart et al. 2010). We searched for statistical differences between both populations based on call features that showed higher DAPC loadings (e.g., dominant frequency) through the "Exact Wilcoxon Mann Whitney Rank Sum Test" in the coin R package (Hothorn et al. 2008).

The morphologically similar species we considered for acoustic comparisons, are those small-sized Scinax with an immaculate color pattern on the hidden surfaces of thigh and groin, and with longitudinal stripes on the dorsum.

\section{Results}

At both sites, males (Figure 1) started calling after sunset and call recordings were made between 19:22 and 20:30 h. We found no evidence of rain the day before recordings. Individuals called hidden, perched on dense, short $(<50 \mathrm{~cm}$ height) grassy bushes in open area marshes. Topotypes are $24.9 \mathrm{~mm} \mathrm{SVL} \mathrm{(SD}$ = 1.2; Range 22.1-26.8 mm; $N=10$ ), and frogs from Poços de Caldas are $23.3 \mathrm{~mm} \mathrm{SVL}$ (SD = 0.4; Range 23.0-23.6).

The advertisement call of topotypes (Table 2, Figure 2) is a stereotyped short, sharp, and pulsed buzz; the call increases in energy to its mid-portion and then decreases. Calls are emitted at a rate of $67 / \mathrm{min}$, last $0.52-0.61 \mathrm{~s}$ and are spaced by inter-call intervals of $0.56-0.66 \mathrm{~s}$. 
Table 1. Acoustic terminology adopted in the present study. Definition of most acoustic traits follows that of Köhler et al. (2017) and Raven manual (Charif et al. 2010).

\section{Acoustic traits}

Call duration (s)

Call interval (s)

Call rate (calls/min)

Notes/call

Note rate (notes/s)

First-note duration (s)

Mid-notes duration (s)

Last-note duration (s)

First-note interval (s)

Mid-notes interval (s)

Last-note interval (s)

First-notes pulse number

Mid-notes pulse number

Last-notes pulse number

Intra-note pulse rate (pulses/s)

Amplitude peak time (\%)

Dominant frequency $(\mathrm{Hz})$

$5 \%$ frequency $(\mathrm{Hz})$

95\% frequency $(\mathrm{Hz})$

\section{Definition}

Time from beginning to end of one call

Time from end of one call to beginning of the consecutive call

Number of calls/time from beginning of first call to beginning of last call; the result is then multiplied by 60 to be given in calls $/ \mathrm{min}$
Number of notes present in one call

Number of notes in one call/call duration

Time from beginning to end of a note in the initial portion of the call

Time from beginning to end of a note in the middle portion of the call

Time from beginning to end of a note in the final portion of the call

Time from end of a note to beginning of the consecutive note (in the initial portion of the call)

Time from end of a note to beginning of the consecutive note (in the middle portion of the call)

Time from end of a note to beginning of the consecutive note (in the final portion of the call)

Number of pulses in notes from the initial portion of the call

Number of pulses in notes from the middle portion of the call

Number of pulses in notes from the final portion of the call

Number of pulses in a mid-call note/note duration

Time from the beginning of the call to its point of maximum amplitude; the value is given as a percentage in relation to the total call duration

Frequency containing the greatest sound energy of the call

Frequency that divides the call into one part above and another below itself, which contain respectively $95 \%$ and $5 \%$ of the total sound energy of the call

Frequency that divides the call into one part above and another below itself, which contain respectively $5 \%$ and $95 \%$ of the total sound energy of the call 
Calls contain 13-15 notes emitted at a rate of $24-27 / s$. Notes from the mid portion of the call are slightly shorter $(0.027-0.028 \mathrm{~s})$ than those at the end (0.020-0.038 s). Mid-call notes have 6 or 7 well-defined pulses with an intra-note pulse rate of 223-266/s. Notes at the end of calls have pulses less clearly defined (values in Table 2 are estimates). The dominant frequency is between 3970 and $4125 \mathrm{~Hz}$, with an average of $370 \mathrm{~Hz}$ upward frequency modulation from beginning until the end of the call; the $90 \%$ bandwidth is $1149 \mathrm{~Hz}$.

Calls of frogs from Poços de Caldas (Table 2, Figure 2) have the same structural pattern as those of the topotypes. Calls are emitted at a rate of $64 / \mathrm{min}$, have durations of $0.46-0.56 \mathrm{~s}$ and are spaced by inter-call intervals of $0.50-0.67 \mathrm{~s}$. Calls contain 15-18 notes emitted at a rate of $32-34 / \mathrm{s}$. Mid-call notes are slightly longer $(0.020-0.025 \mathrm{~s})$ than those at the end $(0.019$ $0.022 \mathrm{~s})$. Notes from mid-call have 6 or 7 welldefined pulses with an intra-note pulse rate of $252-312 / \mathrm{s}$. Notes at the end of call have 6-8 well-defined pulses. The dominant frequency is between 4083 and $4358 \mathrm{~Hz}$; two males had an average of $370 \mathrm{~Hz}$ upward frequency modulation from beginning to the end of call, whereas one had inconsistent variation from -500 to $500 \mathrm{~Hz}$ in relation to the beginning; the $90 \%$ bandwidth is $1476 \mathrm{~Hz}$.

The DAPC completely discriminated $(100 \%$ probability of correct membership) calls of one population from another. The number of notes per call, note rate, and mid-note duration distinguish them. Differences in dominant frequency (wilcox_test $\mathrm{Z}=-1.53, p=0.2$ ), call duration $(Z=1.09, p=0.4)$ and intra-note pulse rate $(Z=-1.53, p=0.2)$ are not significant (Figure 3).

A comparison of the advertisement calls of both populations with those available in literature for other populations of Scinax squalirostris is provided in Table 2. A brief comparison between the advertisement call of our topotypes with those of morphologically similar Scinax species is in Table 3.
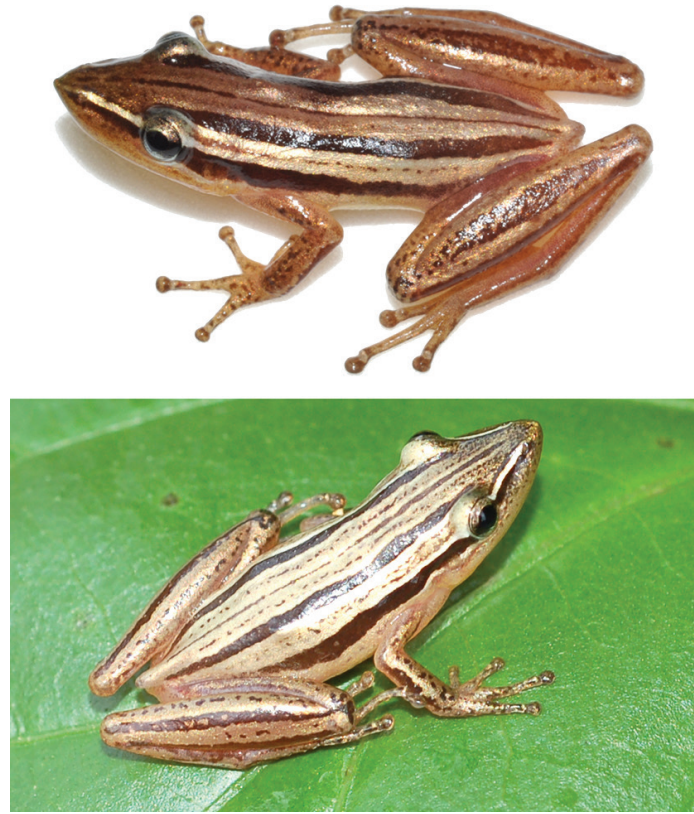

Figure 1. Adult male from each population studied. Above: a topotype of Scinax squalirostris (Serra da Bocaina); AAG-UFU 835. Below: Poços de Caldas, Minas Gerais state; AAG-UFU 4378. Both are call vouchers.

\section{Discussion}

Our call values of topotypic Scinax squalirostris differ from those reported by Faria et al. (2013) (Table 2). Their mean values are consistently lower than their standard deviations, suggesting that the numbers represent minimum and maximum values instead. Considering these inconsistencies, their Table 1 (p. 331; reproduced in Table 7 of Köhler et al. 2017, p. 54) seems to be erroneous. Further, their values for "calls/min" are unrealistic and contrast with those that we found; they are more similar to our values for note rate when expressed in minutes (Table 2 herein). Garey et al. (2018) also provided call data for topotypic $S$. squalirostris and their values for spectral traits differed somewhat from ours (Table 2 ); they reported a substantial high value for the 
Giaretta et al.

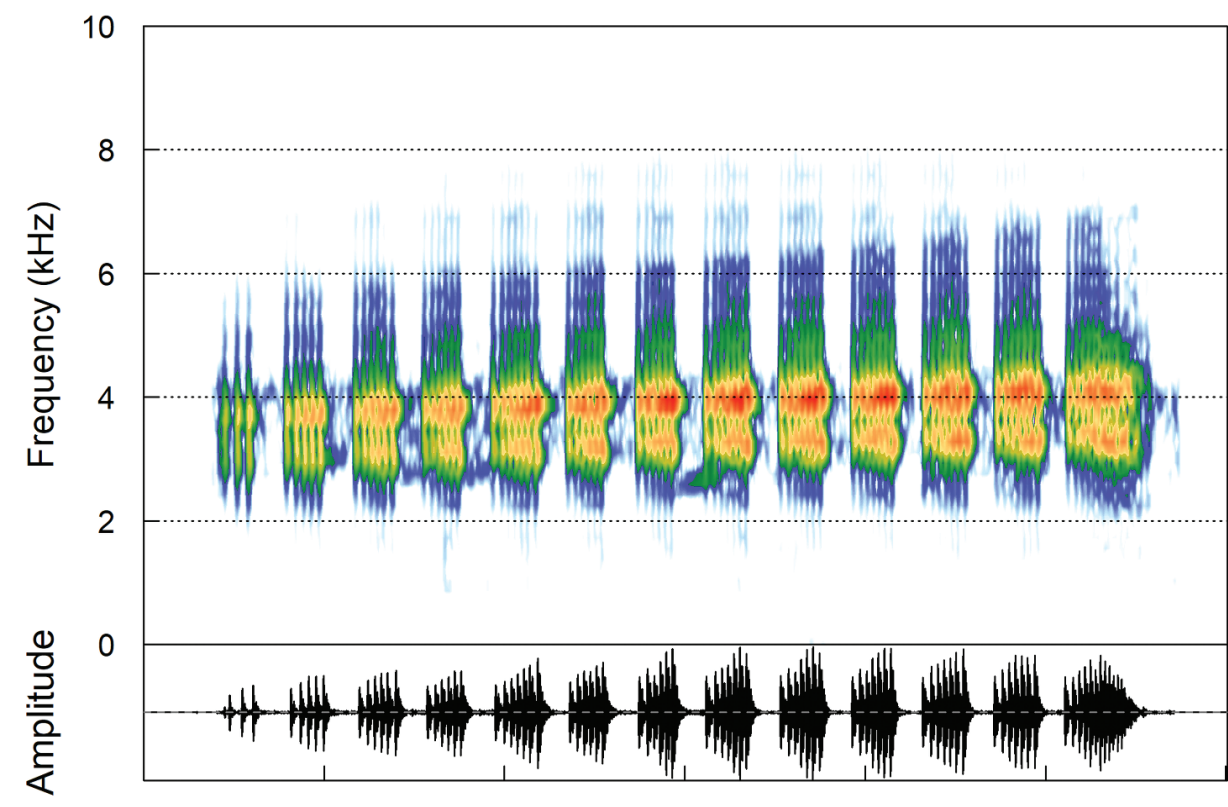

Amplitude (dB)

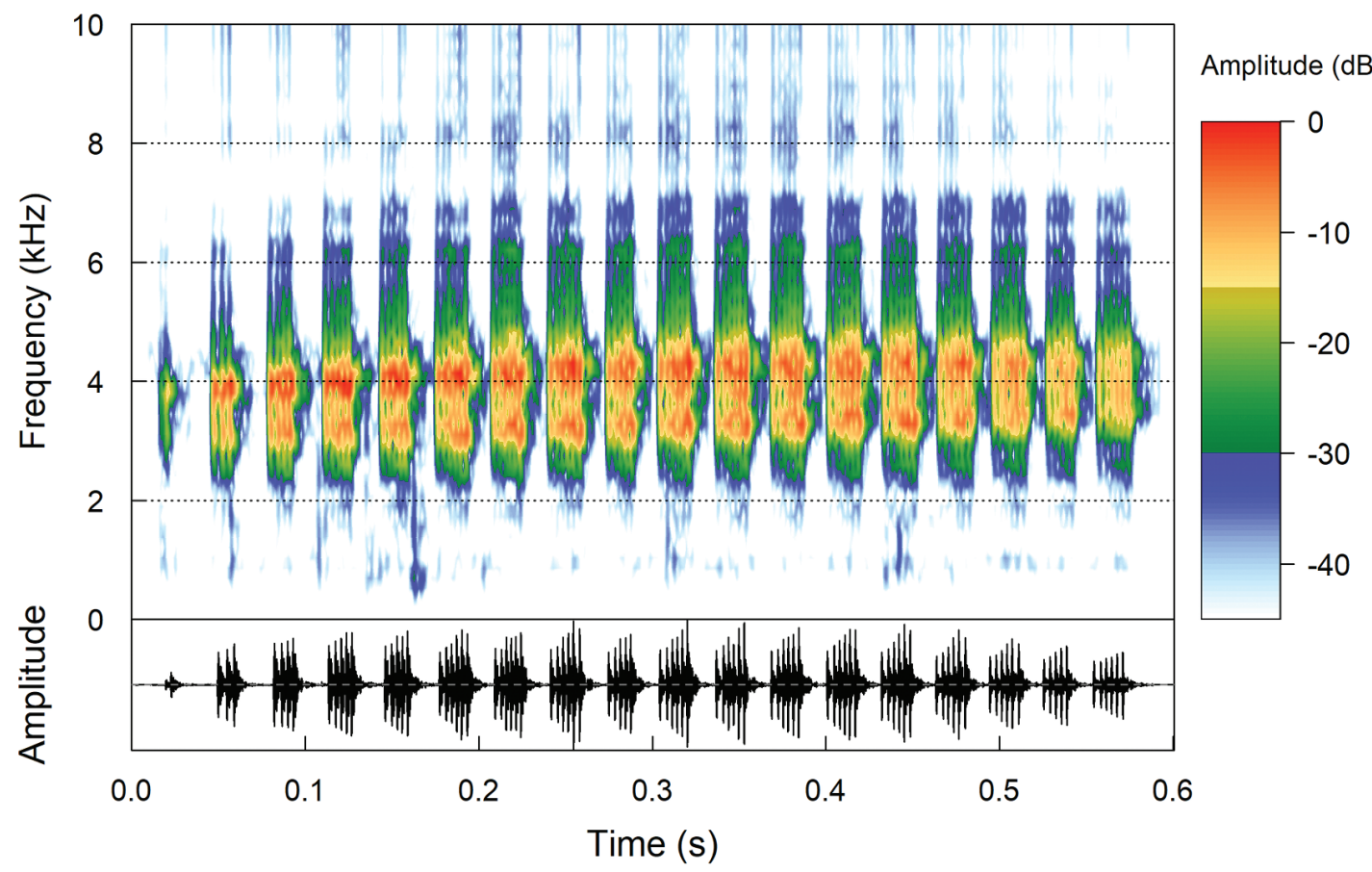

Figure 2. Audiospectrograms and corresponding oscillograms of the advertisement calls of a topotypic Scinax squalirostris (above) and of a male from Poços de Caldas, Minas Gerais state (below). Notice the higher number of notes and shorter note duration of the Poços de Caldas population. Figured recordings: Scinax_ squalirostrisBocainaSP1cAAGm671; Scinax_spPocosCaldasMG1aAAGmt. 

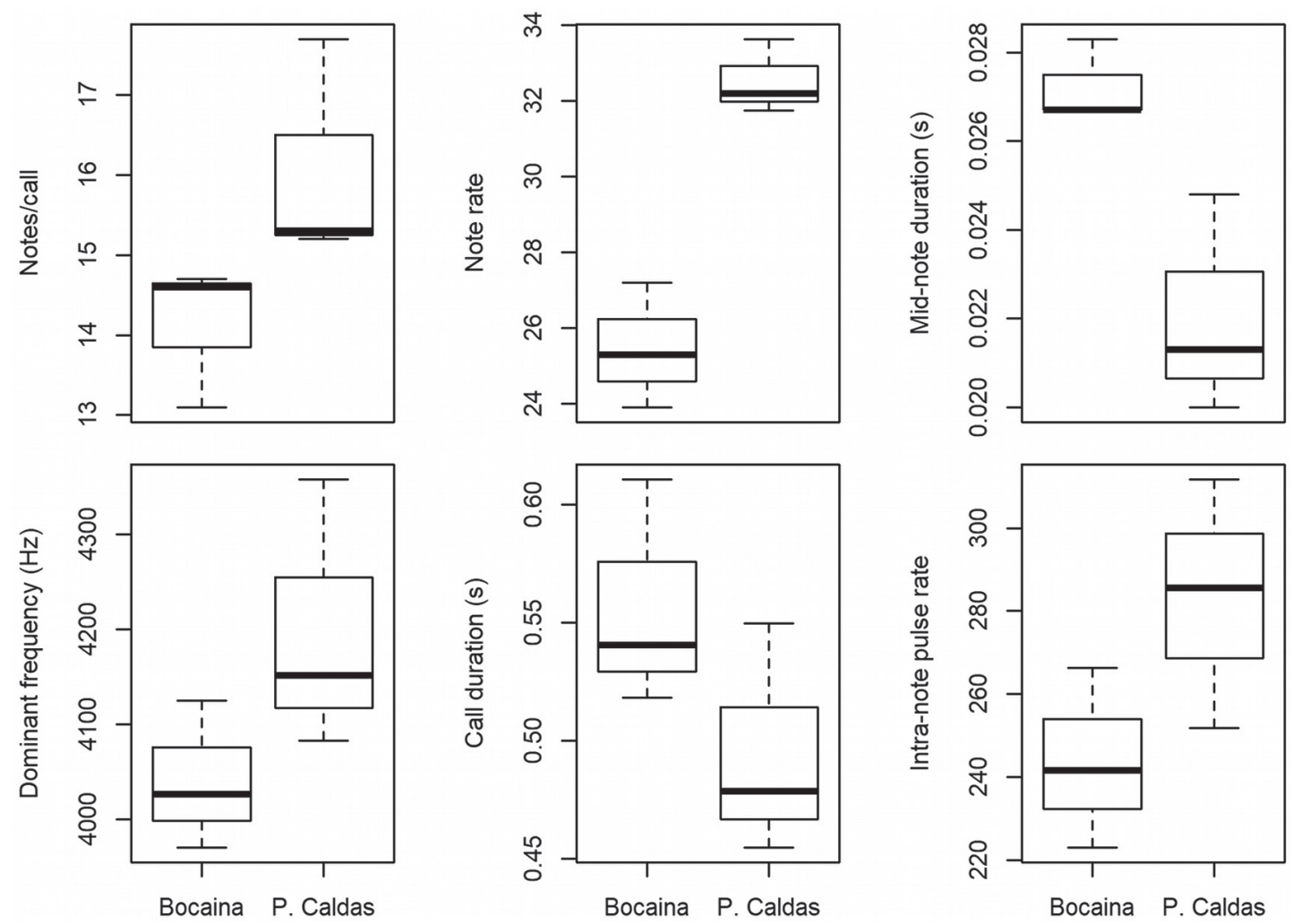

Figure 3. Comparative quantitative call features of the two populations studied. Bocaina represents the type locality of Scinax squalirostris. Notice that the three features above are diagnostic for each. The differences in median values for dominant frequency, call duration, and intra-note pulse rate are not significant $(p>0.05)$. See Table 2 for descriptive statistics.

SD of dominant frequency, but did not discuss it. Based on the re-analysis of the recording of Garey et al. (2018), we noticed that this high SD value results from the alternation of the dominant frequency between emphasized bands along call emissions. Thus, calls in the initial portion of a call series (weak/low amplitude) had their dominant frequencies concentrated in the lower band, whereas calls of middle and last portions of the series (higher and stable amplitude) had more energy in the upper frequency band. Similar between-bands shifts in dominant frequency is known for calls of other species of Scinax (e.g., Magrini et al. 2011, Carvalho et al. 2015, Novaes and Zina 2016, Bang et al. 2017, Lopes et al. 2019). Also, the mean value of notes per call reported by Garey et al. (2018) should be read 10, not 1 (M. V. Garey, pers. com.).

In southeastern Brazil, other populations of frogs identified as Scinax squalirostris are as follow: Alto and Médio Paranapanema (Maffei et al. 2011, Oliveira et al. 2013, Maffei and Ubaid 2014), Paranapiacaba (Trevine et al. 2014), Ribeirão Branco (Pombal et al. 1995), Serra da Canastra (Pombal et al. 1995), Serra do Cipó (Eterovick and Sazima 2004), Serra do Ouro Branco (São-Pedro and Feio 2011), and Triângulo Mineiro (Neves et al. 2019). 
Giaretta et al.

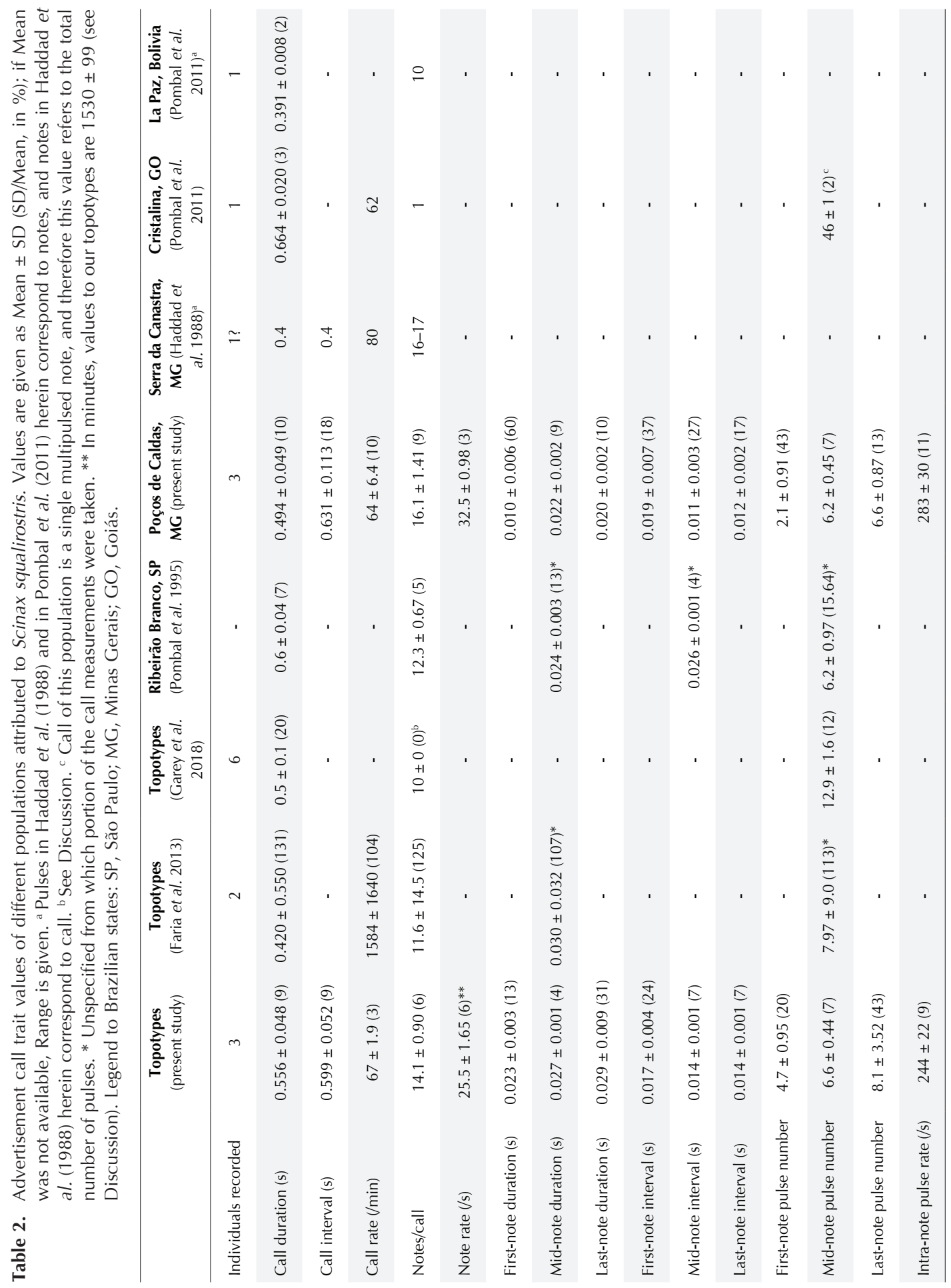




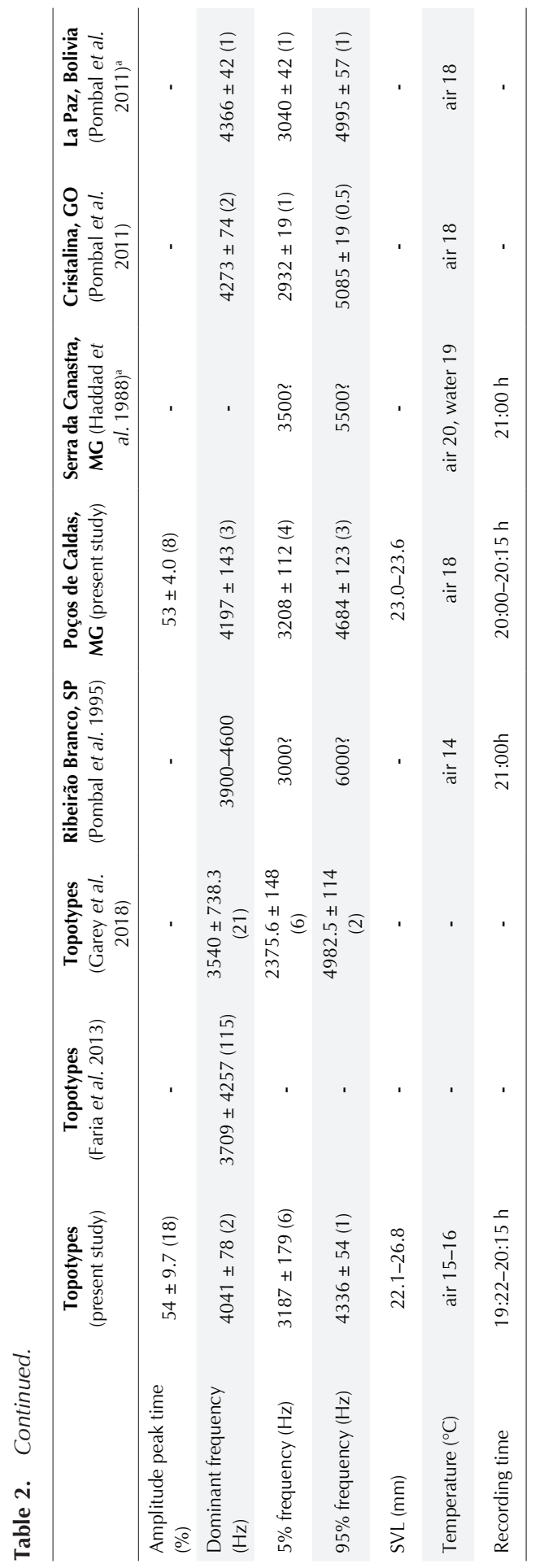

Some of these sites have elevations above $1000 \mathrm{~m}$ and seem to be disjunct from the topotypic population. We think that the substantial interpopulational call differences reported here (Table 2), indicate that a more detailed assessment of the population from Poços de Caldas is needed to clarify whether these differences are within the bounds of natural variation or are diagnostic features of an undescribed taxon. One might expect even more marked differences in populations that are farther from type locality, such as those from Brazilian Cerrado (Haddad et al. 1988, Pombal et al. 2011, Santoro and Brandão 2014), Bolivia, southern Brazil, and Uruguay (Faria et al. 2013). The greater number of notes per call of the populations from Poços de Caldas and Serra da Canastra is noteworthy, as is the longer internote interval of the population from Ribeirão Branco (Table 2). In addition, the call of the frogs from the Cristalina population, Goiás state (GO), differs from those of other populations, since it is composed of a single multi-pulsed note. Examination of different classes of data (e.g., morphometric, acoustic, and molecular) may inform species delimitation within the nominal species $S$. squalirostris and other populations currently assigned this name, such as the one from Poços de Caldas. If a population of frogs at the southernmost part of the range of S. squalirostris is found to be distinct, there are available names for them from southern Uruguay, as well as northeastern and northern Argentina (Klappenbach and Langone 1992, Pinheiro et al. 2014).

Morphologically, Scinax squalirostris is distinguished from its congeners by the combination of its elongated snout and its dorsolateral silvery stripes (Pinheiro et al. 2014). In addition, it differs from morphologically similar congeners by its multi-note advertisement call in contrast to the single-note calls of these species (Table 3 ).

The Poços de Caldas Plateau is rich in endemic frog species (Giaretta and Sazima 1993, Vasconcelos and Giaretta 2003, Caramaschi and 
Giaretta et al.

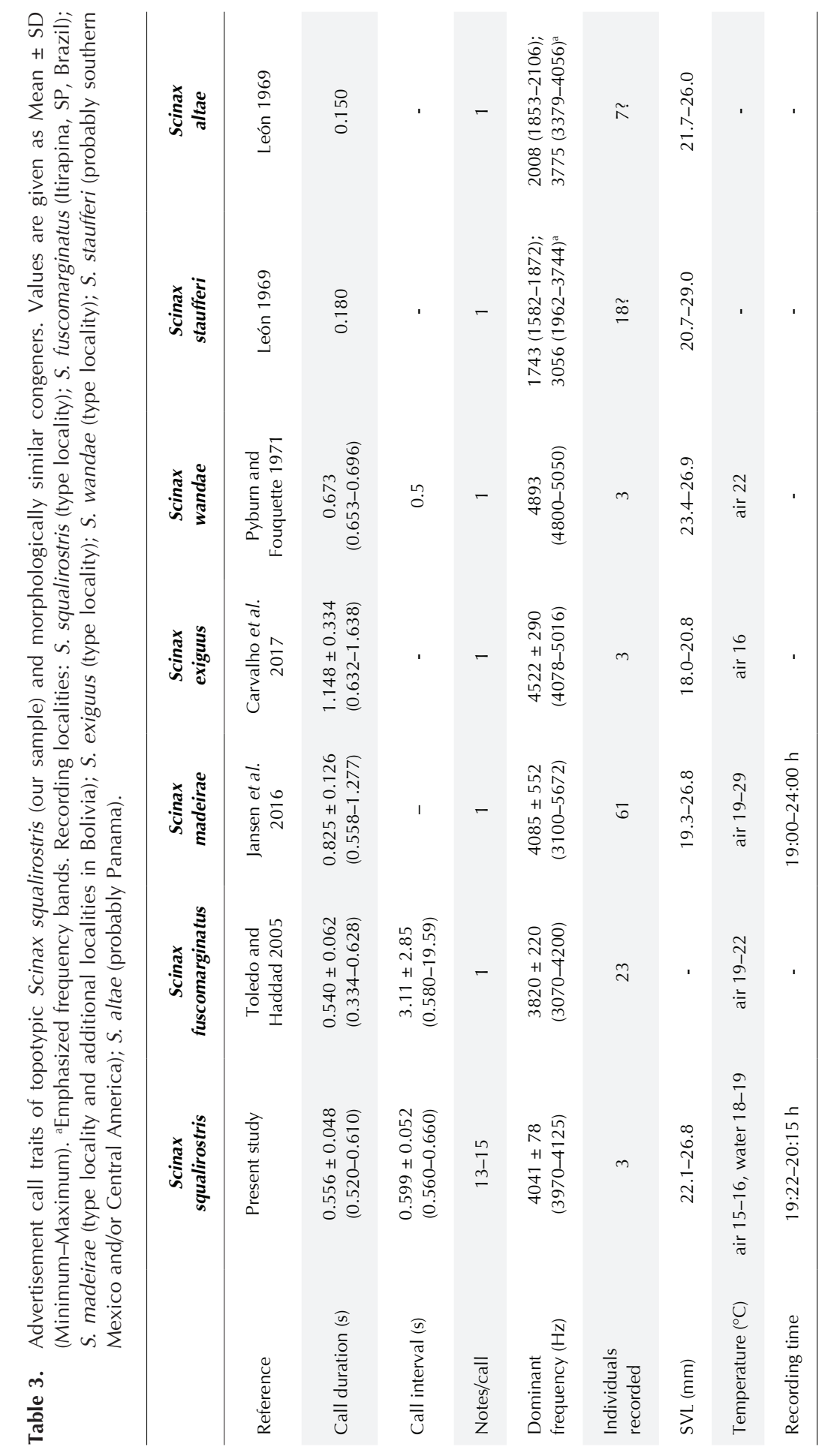


Cruz 2004, Martins et al. 2016), suggesting that the area may have been isolated long enough to result in speciation. Finer taxonomic resolution will improve our understanding of the biogeographic patterns of frog diversification along the vegetation formations of the Atlantic Forest, as exemplified by Vasconcelos et al. (2014), who also verified the presence of Scinax squalirostris in the Mantiqueira Range of Minas Gerais.

\section{Acknowledgments}

Collection permits were issued by ICMBio / SISBIO (\#30059). Financial support was provided by the Conselho Nacional de Desenvolvimento Científico e Tecnológico (CNPq) to the AAG team (446935/2014-0). CNPq also funds a research grant to AAG (300903/2015-4 and 305169/2019-0) and a M.Sc fellowship to AGL (130380/2020-2), and provided a M.Sc. Fellowship to DLB (159817/2015-3). The Fundação de Amparo à Pesquisa do Estado de São Paulo (FAPESP) currently provides a Ph.D. fellowship to DLB (process \#2017/27137-7). The Cornell Lab of Ornithology provided a free license of Raven Pro Software. Dr. M. V. Garey kindly provided a recording from Serra da Bocaina for comparison. Dr. Jörn Köhler and one anonymous reviewer made valuable suggestions on the manuscript. Dr. Linda Trueb revised the accepted version of this manuscript.

\section{References}

Bang, D. L., T. R. C. Carvalho, F. S. Andrade, I. A. Haga, C. S. Bernardes, and A. A. Giaretta. 2017. Vocalization of Scinax haddadorum (Anura: Hylidae), with further notes on the vocalization of the morphologically similar Scinax rupestris. Neotropical Biodiversity 3: 117-124.

Barrio, A. 1963. Influencia de la temperatura sobre el canto nupcial de Hyla squalirostris A. Lutz (Anura, Hylidae). Physis 24: 135-142.

Bioacoustics Research Program. 2014. Raven Pro: Interactive Sound Analysis Software. Version 1.5. URL: http:// www.birds.cornell.edu/raven.
Bokermann, W. C. A. 1966. Lista Anotada das Localidades Tipo de Anfíbios Brasileiros. São Paulo. Serviço de Documentação, RUSP. 183 pp.

Caminer, M. A. and S. R. Ron. 2014. Systematics of treefrogs of the Hypsiboas calcaratus and Hypsiboas fasciatus species complex (Anura, Hylidae) with the description of four new species. Zookeys 370: 1-68.

Caramaschi, U. and C. A. G. Cruz. 2004. Duas novas espécies de Hyla do grupo de $H$. polytaenia Cope, 1870 do sudeste do Brasil (Amphibia, Anura, Hylidae). Arquivos do Museu Nacional 62: 247-254.

Carvalho, T. R., C. S. Cassini, P. P. Taucce, and C. F. B. Haddad. 2019. A new morphologically cryptic species of Adenomera closely related to Adenomera araucaria from the Atlantic Forest of southern Brazil (Anura, Leptodactylidae). Journal of Herpetology 53: 131-143.

Carvalho, T. R., B. F. V Teixeira, W. E. Duellman, and A. A. Giaretta. 2015. Scinax cruentommus (Anura: Hylidae) in the upper Rio Negro drainage, Amazonas state, Brazil, with the redescription of its advertisement call. Phyllomedusa 14: 139-146.

Carvalho, T. R., P. Azarak, D. L. Bang, W. Duellman, and A. A. Giaretta. 2017. A reassessment of the vocalization and distribution of Scinax exiguus (Duellman, 1986) (Anura: Hylidae) in the Amazonian savanna of Roraima, northern Brazil, with the description of its aggressive call. Neotropical Biodiversity 3: 196-202.

Charif, R. A., A. M. Waack, and L. M. Strickman. 2010. Raven Pro 1.4 User's Manual. Version 1.4. Ithaca. Cornell Lab of Ornithology.

De la Riva, I., J. Köhler, S. Lötters, and S. Reichle. 2000. Ten years of research on Bolivian amphibians: updated checklist, distribution, taxonomic problems, literature and iconography. Revista Española de Herpetología 14: $19-164$.

Eterovick, P. C. and I. Sazima. 2004. Anfíbios da Serra do Cipó, Minas Gerais, Brasil. Belo Horizonte. PucMinas. $151 \mathrm{pp}$.

Faria, D. C. C., L. Signorelli, A. R. Morais, R. P. Bastos, and N. M. Maciel. 2013. Geographic structure and acoustic variation in populations of Scinax squalirostris (A. Lutz, 1925) (Anura: Hylidae). North-Western Journal of Zoology 9: 329-336.

Garey, M. V., D. B. Provete, T. Gonçalves-Souza, L. S. Ouchi-Melo, C. F. B. Haddad, and D. C. Rossa-Feres. 2018. Phylogenetic and adaptive components of the anuran advertisement call correlate with temporal species co-occurrence. Biological Journal of the Linnean Society 125: 292-301. 
Giaretta, A. A. and I. Sazima. 1993. Nova espécie de Proceratophrys Miranda-Ribeiro, 1920 do sul de Minas Gerais, Brasil (Amphibia, Anura, Leptodactylidae). Revista Brasileira de Biologia 53: 13-19.

Haddad, C. F. B., G. V. Andrade, and A. J. Cardoso. 1988. Anfíbios anuros do Parque Nacional da Serra da Canastra, estado de Minas Gerais. Brasil Florestal 64: 9-20.

Hothorn, T., K. Hornik, M. A. van de Wiel, and A. Zeileis. 2008. Implementing a class of permutation tests: the coin package. Journal of Statistical Software 28: 1-23.

Jansen, M., M. Plath, F. Brusquetti, and M. J. Ryan. 2016. Asymmetric frequency shift in advertisement calls of sympatric frogs. Amphibia-Reptilia 37: 137-152.

Jombart, T. 2008. Adegenet: a R package for the multivariate analysis of genetic markers. Bioinformatics 24: 1403 1405.

Jombart, T., S. Devillard, and F. Balloux. 2010. Discriminant analysis of principal components: a new method for the analysis of genetically structured populations. Genetics 11: $1-15$.

Klappenbach, M. A. and J. A. Langone. 1992. Lista sistemática y sinonímica de los anfibios del Uruguay con comentarios y notas sobre su distribución. Anales del Museo Nacional de Historia Natural de Montevideo 8: 163-222.

Köhler, J., M. Jansen, A. Rodríguez, P. J. R. Kok, L. F. Toledo, M. Emmrich, F. Glaw, C. F. B. Haddad, M.-O. Rödel, and M. Vences. 2017. The use of bioacoustics in anuran taxonomy: theory, terminology, methods and recommendations for best practice. Zootaxa 4251: $1-124$

Kwet, A. 2001. Frösche im Brasilianischen Araukarienwald. Anurengemeinschaft des Araukarienwaldes von Rio Grande do Sul: Diversität, Reproduktion und Ressourcenaufteilung. Münster. Natur und Tier Verlag. 192 pp.

León, J. R. 1969. The systematic of the frogs of the Hyla rubra group in Middle America. University of Kansas Publications of the Museum of Natural History 18: 505 545.

Lopes, A. G., D. L. Bang, and A. A. Giaretta. 2019. Revisiting the advertisement call features of Scinax montivagus (Anura: Hylidae). Neotropical Biodiversity 5: $41-46$.

Lutz, A. 1925. Batraciens du Brésil. Comptes rendus et mémoires hebdomadaires des séances de la Société de Biologie et des ses filiales. Paris 93: 211-214.
Lutz, B. 1973. Brazilian Species of Hyla. Austin. University of Texas Press. 260 pp.

Maffei, F. and F. K. Ubaid. 2014. Amphibians of Rio Claro Farm, Lençóis Paulista, São Paulo, Brazil. Bauru. Editora Canal 6. 146 pp.

Maffei, F., F. K. Ubaid, and J. Jim. 2011. Anurofauna em área de cerrado aberto no município de Borebi, estado de São Paulo, sudeste do Brasil: uso do habitat, abundância e variação sazonal. Biota Neotropica 11: 201-213.

Magrini, L., S. P. Carvalho-e-Silva, A. F. Bêda, and A. A. Giaretta. 2011. Calls of five species of the Scinax ruber (Anura: Hylidae) clade with comments on their taxonomy. Zootaxa 3066: 37-51.

Martins, L. B., A. A. Giaretta, T. R. Carvalho, and R. Y. Miwa. 2016. Vocalizations of Hypsiboas beckeri and $H$. stenocephalus (Anura: Hylidae), two species of the $H$. polytaenius group from southeastern Brazil. Phyllomedusa 15: 51-64.

Neves, M. O., A. Yves, E. A. Pereira, L. Alves, J. B. Vasques, J. F. T. Coelho, and P. S Silva. 2019. Herpetofauna in a highly endangered area: the Triângulo Mineiro region, in Minas Gerais state, Brazil. Herpetozoa 32: $113-123$.

Novaes, G. and J. Zina. 2016. Advertisement call of Scinax composseabrai (Bokermann, 1968) (Anura: Hylidae), with comments on the call of three species of the Scinax ruber clade. Zootaxa 4084: 258-266.

Nunes, I., A. Kwet, and J. P. Pombal Jr. 2012. Taxonomic revision of the Scinax alter species complex (Anura: Hylidae). Copeia 2012: 554-569.

Oliveira, A. C., C. K. Matsukuma, and S. M. A. Santos. 2013. Composição taxonômica e distribuição de anuros no Alto e Médio Paranapanema, estado de São Paulo. Biota Neotropica 13: 241-258.

Pinheiro, P. D., J. Faivovich, J. A. Langone, and A. Kwet. 2014. The identity of Hyla leucotaenia Burmeister, 1861 (Anura: Hylidae). Zootaxa 3884: 179-184.

Pombal Jr., J. P., R. P. Bastos, and C. F. B. Haddad. 1995. Vocalizações de algumas espécies do gênero Scinax (Anura, Hylidae) do sudeste do Brasil e comentários taxonômicos. Naturalia 20: 213-225.

Pombal Jr., J. P., M. Bilate, P. G. Gambale, L. Signorelli, and R. P. Bastos. 2011. A new miniature treefrog of the Scinax ruber clade from the Cerrado of Central Brazil (Anura: Hylidae). Herpetologica 67: 288-299.

Pyburn, W. F. and M. J. Fouquette Jr. 1971. A new striped treefrog from central Colombia. Journal of Herpetology 5: $97-101$. 
R Development Core Team. 2014. R: A Language and Environment for Statistical Computing. Version 3.1.0. URL: http://wwwR-project.org.

Ron, S. R., W. E. Duellman, M. A. Caminer, and D. Pazmino. 2018. Advertisement calls and DNA sequences reveal a new species of Scinax (Anura: Hylidae) on the Pacific lowlands of Ecuador. PLOS ONE 13: e0203169.

Santoro, G. R. C. C. and R. A. Brandão. 2014. Reproductive modes, habitat use, and richness of anurans from Chapada dos Veadeiros, central Brazil. North Western Journal of Zoology 10: 365-373.

São-Pedro, V. A. and R. N. Feio. 2011. Anuran species composition from Serra do Ouro Branco, southernmost Espinhaço Mountain Range, state of Minas Gerais, Brazil. Check List 7: 671-680.

Straneck, R., E. V. Olmedo, and G. R. Carrizo. 1993. Catálago de Voces de Anfíbios Argentinos / Catalogue of the Voices of Argentine Amphibians. Buenos Aires. Editorial Literature of Latin America. 95 pp.

Sueur, J., T. Aubin, and C. Simonis. 2008. Seewave, a free modular tool for sound analysis and synthesis. Bioacoustics 18: 213-226.

Toledo, L. F. and C. F. B. Haddad. 2005. Acoustic repertoire and calling behavior of Scinax fuscomarginatus (Anura, Hylidae). Journal of Herpetology 39: 455-464.
Toledo, L. F., I. A. Martins, D. P. Bruschi, M. A. Passos, C. Alexandre, and C. F. B. Haddad. 2015. The anuran calling repertoire in the light of social context. Acta Ethologica 18: 87-99.

Trevine, V., M. C. Forlani, C. F. B. Haddad, and Z. Hussam. 2014. Herpetofauna of Paranapiacaba: expanding our knowledge on a historical region in the Atlantic forest of southeastern Brazil. Zoologia 31: 126-146.

Uetanabaro, M., C. P. A. Prado, D. J. Rodrigues, M. Gordo, and Z. Campos. 2008. Guia de Campo dos Anuros do Pantanal e Planaltos de Entorno. Campo Grande. Editora Universidade Federal do Mato Grosso do Sul. $192 \mathrm{pp}$.

Vasconcelos, E. G. and A. A. Giaretta. 2003. A new species of Hyla (Anura: Hylidae) from southeastern Brazil. Revista Española de Herpetologia 17: 21-27.

Vasconcelos, T. S., V. H. M Prado, F. R. da Silva, and C. F. B. Haddad. 2014. Biogeographic distribution patterns and their correlates in the diverse frog fauna of the Atlantic Forest hotspot. PLOS ONE 9: e104130.

Editor: Ignacio De la Riva

Appendix I. List of analyzed sound files (*.wav format); all housed at the collection of frogs of the Universidade Federal de Uberlândia. $m 671$ = marantz/Sennheiser Me67; mt = microtrack/Sennheiser Me67.

Scinax_squalirostrisBocainaSP1aAAGm671; Scinax_squalirostrisBocainaSP1bAAGm671;

Scinax_squalirostrisBocainaSP1cAAGm671; Scinax_squalirostrisBocainaSP2aAAGm671;

Scinax_squalirostrisBocainaSP2bAAGm671; Scinax_squalirostrisBocainaSP2cAAGm671;

Scinax_squalirostrisBocainaSP3aAAGm671; Scinax_squalirostrisPocosCaldasMG1aAAGmt;

Scinax_squalirostrisPocosCaldasMG1bAAGmt; Scinax_squalirostrisPocosCaldasMG2aAAGmt;

Scinax_squalirostrisPocosCaldasMG2bAAGmt; Scinax_squalirostrisPocosCaldasMG3aAAGmt;

Scinax squalirostrisBocainaSP1aMVG_CFBH. 